TOMASZ JUREK

Instytut Historii PAN, Poznań

\title{
„USQUE IN VURTA FLUVIUM”. NAD TRYBUTEM MIESZKOWYM
}

\begin{abstract}
Abstrakt: Artykuł dotyczy zagadnienia stosunków najstarszego władztwa piastowskiego w X w. do cesarstwa Ottonów. Przedmiotem analizy jest zdanie kronikarza Thietmara z Merseburga z jego dzieła (II 29), iż polski książę Mieszko płacił cesarzowi trybut „aż do rzeki Warty”. Wbrew rozpowszechnionym poglądom autor artykułu uważa, że chodziło o całe terytorium władztwa Mieszka, a obowiązek trybutarny ustanowiony został w $963 \mathrm{r}$.
\end{abstract}

Słowa kluczowe: Cesarstwo Ottonów, Mieszko I, monarchia pierwszych Piastów, trybut, stosunki polsko-niemieckie.
Abstract: The article deals with relations between the oldest Piast rulers from the tenth century and the Ottonian Empire. The analysis focuses on a sentence by chronicler Thietmar of Merseburg (II, 29), who wrote that the Polish Duke Mieszko paid a tribute to the emperor "all the way to the river Warta". Contrary to disseminated views, the author of the article is of the opinion that the chronicler had in mind the whole territory of the Mieszko dominion and that the obligatory tribute was established in 963.

Keywords: Ottonian Empire, Mieszko I, Early Piast monarchy, tribute, Polish-German relations.

Niewiele jest ustępów źródłowych, nad którymi z równym wysiłkiem głowią się od pokoleń historycy, jak słowa saskiego kronikarza Thietmara, przytoczone w tytule niniejszego szkicu. Przypomnijmy całe zdanie, z którego zostały wyjęte: „Tymczasem dostojny margrabia Hodo zebrawszy wojsko, zaatakował Mieszka, wiernego cesarzowi i płacącego trybut aż do rzeki Warty"1. Wyprawa zakończyła się, jak wiadomo, klęską Sasów

1 „Interea Hodo venerabilis marchio Miseconem inperatori fidelem tributumque usque in Vurta fluvium solventem exercitu petivit collecto”, Die Chronik des Bischofs Thietmar von Merseburg, wyd. R. Holtzmann, Berlin 1935, MGH SrG n.s., t. 9 
w bitwie stoczonej pod Cedynią w dniu 24 czerwca (z kontekstu wynika, że chodzi o rok 972)2 ${ }^{2}$. Wtrącone w relację o wypadkach wojennych słowa przynoszą kluczowe informacje o statusie Mieszka i jego władztwa. Był „wierny cesarzowi” (dawno już wykazano, że nie chodzi tu o pozycję wasala, lecz wierność w ogólnym sensie oddanego dotrzymywania zobowiązań) ${ }^{3}$ i płacił trybut. Nigdy w zasadzie nie kwestionowano wiarogodności tego przekazu ${ }^{4}$. Thietmar pisał zaledwie kilkadziesiąt lat później (w drugim dziesięcioleciu XI w.), sam był biskupem, pochodził z saskiej arystokracji, uczestniczącej w życiu publicznym (jego ojciec Zygfryd brał osobiście udział w nieszczęsnej wyprawie cedyńskiej), i był świetnie zorientowany we wszystkich sprawach słowiańskiego pogranicza. Miał swe uprzedzenia - nie znosił Bolesława Chrobrego - które rzutować mogły na tendencyjne podkreślanie trybutarnego niegdyś statusu Piastó $^{5}$, ale nie przesłaniały one chyba rzetelności tej bogatej w szczegóły relacji. Niegasnąca dyskusja historyków toczy się natomiast wokół ustalenia, jaki był zasięg tego trybutarnego obowiązku. Wskazanie rzeki ma bowiem wyraźnie charakter ograniczający: trybutarne terytorium sięga do niej i nie dalej. Ustalenie, z jakiego obszaru Mieszko opłacał trybut cesarzowi, ma oczywiście podstawowe znaczenie dla zrozumienia istoty ich wzajemnych stosunków.

Nic więc dziwnego, że wokół interpretacji prostych z pozoru słów kronikarza narastały różnorakie wątpliwości. Literatura dotycząca tego zagadnienia jest ogromna, jako że każdy historyk, piszący o X w. i początkach państwa piastowskiego, musiał się nad tą kwestią zatrzymać.

(dalej: Thietmar), lib. II, cap. 29, s. 74. Cytat według uznawanego za autograf rękopisu drezdeńskiego (podobizna: http://www.mgh-bibliothek.de/thietmar/fol.0029.html). W podanej równolegle w druku (s. 75) wersji z rękopisu korwejskiego (który uznaje się za ostateczną redakcję autorską) występują jedynie drobne różnice („Wurta”, „collecto exercitu”). Tłumaczenie polskie: Kronika Thietmara, wyd. M.Z. Jedlicki, Poznań 1953, s. 88-92.

2 O bitwie pod Cedynią zob. niżej, przyp. 40.

${ }_{3}^{3}$ M.Z. Jedlicki, Stosunek prawny Polski do Cesarstwa do r. 1000, Poznań 1939, s. 38-39.

${ }^{4}$ Tylko Kazimierz Tymieniecki (rec.: Gerard Labuda, Studia nad początkami państwa polskiego, Poznań 1946, „Slavia Occidentalis” 19, 1948, s. 468) deklarował, że nie uważa wiadomości Thietmara za „murowaną” i nie wie, jak było naprawdę, acz nie przytoczył poważnych argumentów, poza spostrzeżeniem, że wiadomość ta „nie ma żadnego oparcia w znanych faktach politycznych", i domysłem, że może być zmyślona. W ten sposób można zdezawuować każde źródło. W późniejszych swych pracach (Początki państwa Polan, PH 50, 1959, s. 28-30; Polska w średniowieczu, Warszawa 1961, s. 54) Tymieniecki uważał trybut za niebyły. Wątpliwości tych potem nie podjęto.

${ }^{5}$ A. Pleszczyński, Niemcy wobec pierwszej monarchii piastowskiej (963-1034). Narodziny stereotypu. Postrzeganie i cywilizacyjna klasyfikacja władców Polski i ich kraju, Lublin 2008, s. $64-71$. 
Nie ma tu miejsca, by dokładnie analizować wszystkie zgłaszane propozycje. Wystarczy wskazać główne nurty dotychczasowych interpretacji ${ }^{6}$. Najstarsza i najprostsza była wykładnia, że trybut ciążył na posiadanych przez Mieszka ziemiach na zachód od Warty. Wydawało się bowiem oczywiste, że dla właściwego zrozumienia Thietmarowych słów konieczne jest przyjęcie perspektywy kronikarza: chodzić musi o obszar leżący od strony Niemiec, patrząc od zachodu aż do wskazanej rzeki. Taką interpretację przyjęła większość historyków niemieckich ${ }^{7}$, niewiele zresztą zajmujących się sprawą, z ich punktu widzenia drugorzędną i nie wymagającą głębszego zastanowienia. Większy wysiłek w analizę słów kronikarza wkładali historycy polscy, zdający sobie sprawę ze znaczenia tego przekazu dla naświetlenia stosunków zagranicznych rodzącego się władztwa piastowskiego. Od samego początku krytycznej historiografii doceniano wagę sprawy dla obrony tezy o pradawnej suwerenności Polski ${ }^{8}$. Intensywniejsze badania nad tymi zagadnieniami rozwinięto jednak dopiero w epoce międzywojennej, w atmosferze konfrontacji z nauką niemiecką. Oczywisty po obu stronach był cel polityczny. Naszym badaczom chodziło o minimalizowanie za wszelką cenę znaczenia wpływów niemieckich na rodzące się państwo polskie ${ }^{9}$. Sprawa trybutu miała tu fundamentalne znaczenie. Nie mogąc zaprzeczyć samemu jego istnieniu, starano się przynajmniej ograniczyć jego znaczenie. Stąd pomysł, że Mieszko płacił trybut z jakiegoś cząstkowego tylko obszaru, położonego możliwie peryferyjnie. Były więc luźno rzucane supozycje, wskazujące nawet na obszary położone za Odrą ${ }^{10}$ (skąd zatem w ogóle

${ }^{6}$ Szczegółowe omówienie literatury znajduje się w wielu z cytowanych niżej prac, zwłaszcza u G. Labudy i Edwarda Rymara, a także w komentarzu w: Kronika Thietmara, s. 88-92.

${ }^{7}$ Np. R. Köpke, E. Dümmler, Kaiser Otto der Große, Leipzig 1876, Jahrbücher der deutschen Geschichte, s. 385; R. Holtzmann, Geschichte der sächsischen Kaiserzeit (9001024), München 1941, s. 188-189; F. Baethgen, Zur Geschichte der ältesten deutsch-polnischen Beziehungen, „Altpreußische Forschungen” 13, 1936, s. 4-6.

8 J.S. Bandtkie, Dzieje narodu polskiego, t. 1, Wrocław 1835, s. 130. W odpowiedzi Friedrich Wilhelm Barthold (Geschichte von Rügen und Pommern, t. 1, Hamburg 1839, s. 285) stwierdzał, że to tylko „Nationalstolz” nie pozwala Polakom przyznać, iż obszar trybutarny leżał na lewym brzegu Warty i obejmował kolebkę ich państwowości, więc szukają go na siłę na brzegu prawym.

${ }^{9}$ Odosobniony był głos Feliksa Pohoreckiego (rec. pracy Mariana Zygmunta Jedlickiego, La création du premier archevêché polonais à Gniezno, Paris 1933, KH 48, 1934, s. 142), który poparł stanowisko badaczy niemieckich i widział obszar trybutarny na zachód od Warty.

10 W. Bogusławski, Dzieje Słowiańszczyzny Pótnocno-Zachodniej do połowy XIII w., t. 3, Poznań 1892, s. 276; zob. w aktualnym do dziś podręczniku: R. Grodecki, S. Zachorowski, J. Dąbrowski, Dzieje Polski średniowiecznej, wyd. 2, t. 1, Kraków 1995 (1 wyd. 1926), 
u Thietmara Warta?). Nie sposób z nimi poważnie dyskutować. Ponieważ walki toczono na Pomorzu, wydawało się niektórym historykom, że to tu, a więc już za dolną Wartą, najlepiej szukać trybutarnego obszaru. Taką sugestię czynił Stanisław Zakrzewski ${ }^{11}$, a myśl tę szeroko rozwinął Józef Widajewicz ${ }^{12}$, ale i z jego przekombinowanymi konstrukcjami trudno rzeczowo dyskutować (założył bowiem, że trybut płacony był tylko z ziem plemienia „Licicaviki”, które dość dowolnie umieścił u ujścia Warty do Odry). Bardziej zdyscyplinowany i rozbudowany wywód przeprowadził Marian Zygmunt Jedlicki ${ }^{13}$. Przeanalizowawszy wszystkie występujące w źródłach rodzaje trybutów, drogą eliminacji innych możliwości wskazał, że w tym przypadku chodzić musiało o wykup jakichś praw cesarskich przez piastowskiego władcę - co najłatwiej uzasadnić właśnie w odniesieniu do Pomorza. Cesarz w zamian za trybut odstąpić miałby Mieszkowi swe roszczenia do tej ziemi, wynikające z ogólnych wyobrażeń o zwierzchności cesarskiej nad światem. Niezależnie od erudycyjnego wysiłku twórcy tej konstrukcji brzmi ona sztucznie i mało przekonująco, tym bardziej że badacz ten po drodze do swej tezy pomorskiej dość obcesowo eliminował inne rozwiązania (jak np. podstawowa forma trybutu jako wykupu od zagrożenia najazdem). Nadal pozostaje niezrozumiałe, dlaczego terytorium położone (zarówno ze strony piastowskiego płatnika, jak i merseburskiego narratora) za Wartą zostało określone jako sięgające do tej rzeki. Gdyby rzeczywiście obszarem trybutarnym było całe Pomorze, prościej i jaśniej byłoby napisać, że sięgał on „usque in mare” itp. Hipoteza pomorska, starająca się dopasować do kontekstu opowieści kronikarza o wojnie Hodona z Mieszkiem, w istocie wcale do niej nie pasuje. Po cóż bowiem Thietmar, sympatyzujący wyraźnie z saskim margrabią, miałby podkreślać,

s. 66, gdzie jednak do tekstu wkradły się, jak się wydaje, jakieś błędy. Do hipotezy zaodrzańskiej gotów był wrócić jeszcze Kazimierz Myśliński (Polska wobec Słowian Połabskich do końca wieku XII, Lublin 1993, s. 31), sugerujący ostrożnie, że mogło chodzić o ziemię połabskich Wkrzan i część Łużyc.

11 S. Zakrzewski, Mieszko I jako budowniczy państwa polskiego, wyd. 2, Kraków 2006 (1 wyd. Warszawa 1921), s. 93-94, który jednak przede wszystkim brnął w absurdalny wywód, jakoby słowa „usque in Vurta fluvium” nie odnosiły się wcale do obszaru trybutarnego, lecz wskazywały kierunek marszu Hodona.

12 J. Widajewicz, Licicaviki Widukinda. Studium onomastyczno-geograficzne, „Slavia Occidentalis" 6, 1927, s. 85-182; idem, Polski obszar trybutarny w X wieku, Sobótka 2, 1947, s. 47-92.

${ }^{13}$ M.Z. Jedlicki, op. cit., zwł. s. 119 n. Między akceptacją dla tez Widajewicza i Jedlickiego wahał się Zygmunt Wojciechowski, Usque in Vurta fluvium, w: Wirtschaft und Kultur. Festschrift zum 70. Geburtstag von Alfons Dopsch, Baden bei Wien-Leipzig 1938, s. 289-299; idem, Polska - Niemcy. Dziesięć wieków zmagania, Poznań 1945, s. 17. 
że wkroczył on zbrojnie na terytorium zarządzane za zgodą cesarską przez przeciwnika?

Hipotezę pomorską poddał stanowczej krytyce Gerard Labuda, który przedstawił własną propozycję rozwiązania zagadki ${ }^{14}$. Też wychodząc od kluczowej jakoby nazwy „Licicaviki”, zidentyfikował ich z Lubuszanami, siedzącymi po obu stronach środkowej Odry, a swą północną krawędzią sięgającymi Warty. Mieszko zajął ten obszar, podporządkowany już wcześniej Cesarstwu, w związku z czym przejąć musiał też ciążące na nim zobowiązania trybutarne. Autorytet naukowy G. Labudy sprawił, że teza ta zyskała sobie spore uznanie ${ }^{15}$. Spotkała się też jednak z zasłużoną krytyką, bo rzeczywiście budzi cały szereg zastrzeżeń. Opiera się na spiętrzeniu niesprawdzalnych domysłów. Nazwę „Licicaviki” wykłada się obecnie jako Lestkowice (w znaczeniu ogółu poddanych Piastów) ${ }^{16}$, plemię Lubuszan nie jest skądinąd znane (poza jedną niepewną wzmian$\mathrm{ką})^{17}$, nic nie wiadomo więc, by kiedykolwiek podbili je Sasi, a mało prawdopodobne wydaje się, by Mieszko poważył się zajmować obszar podlegający już wcześniej cesarzowi. Niepewny pozostaje związek tego terytorium z Wartą. Zauważono, że dolny odcinek tej rzeki (na którym opierała się północna granica późniejszej ziemi lubuskiej) uważano w średniowieczu często za fragment Noteci (której Warta miałaby być dopływem, wpadającym pod Santokiem) ${ }^{18}$. Choć trudno zaręczyć,

14 G. Labuda, Studia nad początkami państwa polskiego, Poznań 1946, s. 141-162; zob. też wyd. 2, t. 1, Poznań 1987, s. 485-495, gdzie dyskusja z krytykami; poglądom swym autor pozostał wierny (idem, Mieszko I, Wrocław 2002, s. 124-126; idem, Pierwsze wieki monarchii piastowskiej, Poznań 2012, s. 45-46), aczkolwiek był moment, że gotów był się chyba z nich wycofać (idem, Fragmenty dziejów Słowiańszczyzny Zachodniej, t. 1, Poznań 1960, s. 289, przyp. 163).

${ }_{15}$ Np. J. Strzelczyk, Mieszko Pierwszy, Poznań 1992, s. 152-157 (bardzo ostrożnie); S. Szczur, Historia Polski. Średniowiecze, Kraków 2002, s. 48-49; Ch. Lübke, Das östliche Europa, München 2004, Die Deutschen und das europäische Mittelalter, s. 189; E. Mühle, Die Piasten. Polen im Mittelalter, München 2011, s. 17-18. Nawet Jerzy Dowiat (Metryka chrztu Mieszka I i jej geneza, Warszawa 1961, s. 181-184), choć miał odmienny pogląd (zob. niżej, przyp. 21), przyznawał, że lubuska hipoteza, aczkolwiek oparta na samych domysłach, ,jest stosunkowo najmniej nieprawdopodobna”.

16 Zob. sam G. Labuda, Licicaviki, SSS, t. 3, cz. 1, red. W. Kowalenko, G. Labuda, Z. Stieber, Wrocław 1967, s. 56; por. idem, Studia, wyd. 2, t. 2, Poznań 1988, s. 62-80; J. Strzelczyk, op. cit., s. 93-96.

17 Zob. R. Kiersnowski, Lubuszanie, SSS, t. 3, cz. 1, s. 101.

${ }^{18}$ H. Ludat, Mieszkos Tributpflicht bis zur Warthe, „Deutsches Archiv für Landes- und Volksforschung" 2, 1938, s. 380-385 (tłum. pol.: Mieszko Pierwszy i jego trybut usque in Vurta fluvium, w: idem, Słowianie - Niemcy - Europa. Wybór prac, Marburg-Poznań 2000, s. 27-33); idem, Warthe oder Netze?, „Beiträge zur Namensforschung” 3, 1951/1952, s. 213-221 (tłum.: Warta czy Noteć?, w: Słowianie - Niemcy - Europa, s. 34-41); zob. Słownik 
że w X w. też obowiązywała taka nomenklatura, wszystko to budzi bardzo poważne wątpliwości. Hipoteza lubuska również okazuje się więc słaba i nieprzekonująca. I ona pozostawia zresztą wątpliwość, po co Thietmar wspominał w ogóle o tym peryferyjnym terytorium w kontekście walk pod Cedynią. Niewiele wniósł nowego do określenia podstaw terytorialnych trybutu Henryk Łowmiański, który skądinąd całkowicie przewrócił zagadnienie, uznając, że chodziło o czynsz kościelny na rzecz Magdeburga, co z różnych przyczyn ostać się nie może ${ }^{19}$.

Zarzuconą już, zdawałoby się, hipotezę pomorską próbował reanimować na zupełnie nowej podstawie Edward Rymar $^{20}$. Nawiązał on do swych szerszych koncepcji, jakoby trybut płacony przez Mieszka z Pomorza stanowił kontynuację powinności ciążących na tej ziemi od czasów karolińskich. Pomysł ten - sam w sobie nader wątpliwy - nie wyjaśnia w niczym zastrzeżeń, jakie hipoteza pomorska budziła już w swych poprzednich wcieleniach.

Na zupełnie nowe tory próbował sprowadzić zagadnienie Jerzy Dowiat, sugerując, że obszarem trybutarnym był śląsk - z tego mianowicie tytułu, iż Mieszko zdobył go na Czechach, a oni płacili wcześniej trybut z całego swego władztwa ${ }^{21}$. Oryginalny pomysł pozostawał długo niezauważony, po latach odświeżył go Sławomir Moździoch, ale i on nie znalazł oddźwięku' ${ }^{22}$. Rozwiązanie takie wymagałoby dodatkowego udowodnienia, że Śląsk należał do Mieszka już ok. 970 r. (co wydaje się mocno wątpliwe, a co Dowiat próbował wyminąć karkołomną tezą, jakoby Thietmar miał na myśli sytuację o kilkadziesiąt lat późniejszą) i że ziemia ta sięgała wtedy Warty (z czym wiąże się trudna do rozstrzygnięcia kwestia domniemanego plemienia Poobrzan) ${ }^{23}$. Hipotezę śląską jeszcze trudniej

historyczno-geograficzny województwa poznańskiego w średniowieczu, cz. 3, red. A. Gąsiorowski, Poznań 1993-1999, s. 313, 316; jeszcze Jan Długosz miał wątpliwości co do nazwy dolnego odcinka rzeki (Ioannis Dlugossii Annales seu cronicae incliti Regni Poloniae, ks. 1-2, red. J. Dąbrowski, Varsaviae 1964, s. 74-75, 81-82).

${ }_{19}$ H. Łowmiański, Imię chrzestne Mieszka I, „Slavia Occidentalis” 19, 1948, s. 297-305 (przedruk w: idem, Studia nad dziejami Słowiańszczyzny, Polski i Rusi w wiekach średnich, Poznań 1986, s. 349-353); idem, Początki Polski, t. 5, Warszawa 1973, s. 539-546; zob. trafną krytykę G. Labudy, Studia, wyd. 2, t. 1, s. 489 n.

${ }^{20}$ Najpełniej E. Rymar, Terytorium usque in Vurta fluvium, czyli Pomorze obszarem trybutarnym Niemiec za Mieszka I, w: Biskupi, lennicy, żeglarze, red. B. Śliwiński, Gdańsk 2003, Gdańskie Studia z Dziejów Średniowiecza, 9, s. 189-228; krytycznie zob. J.M. Piskorski, Pomorze plemienne. Historia - archeologia - językoznawstwo, Poznań-Szczecin 2002, s. 53-56.

${ }^{21}$ J. Dowiat, op. cit., s. 178-190.

22 S. Moździoch, Śląsk między Gnieznem a Praga, w: Ziemie polskie w X wieku i ich znaczenie w kształtowaniu się nowej mapy Europy, red. H. Samsonowicz, Kraków 2000, s. 176-177.

${ }^{23}$ Ibidem, s. 173 n.; krytycznie o tej tezie K. Jaworski, Pobarane - Bobrzanie 
niż pomorską byłoby wreszcie wmontować w kontekst opowieści Thietmara. Po co byłyby czytelnikowi opisu wyprawy Hodona ciekawostki o sytuacji politycznej śląska? I ten pomysł nie nadaje się więc do akceptacji. Zbyt wiele tu znaków zapytania i niesprawdzonych domysłów.

Osobnym nurtem rozwijały się poglądy historyków niemieckich. Kilku z nich, znających język polski, pod wpływem mnożących się w polskiej literaturze hipotez także zajęło się bliżej zagadkowym trybutem do Warty. Podkreślali przede wszystkim osobliwość tego ograniczenia terytorialnego, skoro trybuty - o czym będzie też mowa niżej - ciążyły z zasady na całych ludach czy władztwach. Wyjaśnienie znajdowano więc $\mathrm{w}$ domyśle o specjalnym przywileju cesarskim, mocą którego Otto darował piastowskiemu księciu w pewnym momencie część szerszej początkowo należności ${ }^{24}$, albo - do czego doszedł Gerhard Sappok w założeniu, że Warta podana jest tu jako granica zewnętrzna władztwa Mieszka, które w całości objęte zostało trybutem ${ }^{25}$. Ta ostatnia teza, ogłoszona już w czasie wojny w mocno zideologizowanym periodyku, przeszła słabo zauważona ${ }^{26} \mathrm{i}$ późniejsi historycy niemieccy wracali raczej do tradycyjnego poglądu o trybucie z obszaru na lewym brzegu Warty. Do dziś panuje on w miarodajnych opracowaniach niemieckich ${ }^{27}$, choć autorzy znający lepiej polskie badania wolą się odwoływać do nich ${ }^{28}$. Do tezy Sappoka nawiązał jednak, chyba nieświadomie, a w każdym razie bez stosownego przypisu, historyk prawa (z zawodu zaś bankowiec)

czy Obrzanie?, w: Viae historicae. Księga jubileuszowa dedykowana Profesorowi Lechowi A. Tyszkiewiczowi w siedemdziesiata rocznice urodzin, red. M. Goliński, S. Rosik, Wrocław 2001, s. 178-188; dyskusję o losach Śląska podsumowali ostatnio: E. Kowalczyk, Momenty geograficzne państwa Bolesława Chrobrego. Na styku historii i archeologii, KH 107, 2000, 2, s. 68-73; D.A. Sikorski, Początki Kościoła w Polsce. Wybrane problemy, Poznań 2012, s. 90-104.

${ }^{24}$ H. Ludat, Die Anfänge des polnischen Staates, Krakau 1942, s. 28, 33-35; zob. też wyżej, przyp. 18.

${ }^{25}$ G. Sappok, Die Anfänge des Bistums Posen und die Reihe seiner Bischöfe von 968-1498, Leipzig 1937, s. 16-42 (tu jeszcze sprawa nierozstrzygnięta); idem, Polens Tributpflicht gegenüber dem Deutschen Reiche im 10. Jahrhundert, „Deutsches Archiv für Landes- und Volksforschung" 5, 1941, s. 260-270.

${ }^{26}$ Odnotował ją H. Łowmiański, Imię, s. 299, choć nie poświęcił jej wiele uwagi.

${ }^{27} \mathrm{~Np}$. A. Angenendt, Kaiserherrschaft und Königstaufe. Kaiser, Könige und Päpste als geistliche Patrone in der abendländischen Missionsgeschichte, Berlin-New York 1984, s. 297; J. Fried, Der Weg in die Geschichte. Die Ursprünge Deutschlands bis 1024, Berlin 1998, s. 659; H. Keller, G. Althoff, Die Zeit der späten Karolinger und der Ottonen. Krisen und Konsolidierungen 888-1024, Stuttgart 2008, Gebhardt. Handbuch der deutschen Geschichte, wyd. 10, t. 3, s. 236.

${ }^{28}$ B. Stasiewski, Die Anfänge der Christianisierung Polens auf dem Hintergrund der slavischen Missionsgeschichte des frühen Mittelalters, Münster 2014, s. 273-275; zob. przyp. 15. 
Gernot von Grawet-May ${ }^{29}$. Nie wchodząc w głębsze analizy, stwierdził on, że obszaru trybutarnego szukać trzeba nie na prawym (północnym), lecz na lewym (południowym) brzegu granicznej Warty, a obejmował on całe władztwo piastowskie. Taka była bowiem istota trybutu, nakładanego z zasady na całe ludy. I ta wypowiedź przeszła jednak niemal niezauważona. Dobrze w Polsce znaną ${ }^{30}$, ale dotyczącą nieco innej problematyki (prawnopaństwowego stanowiska śląska) książkę rzadko bowiem czytywali historycy czasów Mieszka I. Myśl podchwycił, o ile mi wiadomo, jedynie Jarosław Sochacki, który jednak poglądu tego szerzej nie rozwinął ${ }^{31}$.

Właśnie zaś hipoteza G. Sappoka i Gernota von Grawerta-Maya wydaje się, mimo mało sympatycznego kontekstu, w jakim została po raz pierwszy zgłoszona, najbardziej przekonująca. Na jej rzecz przemawia już podstawowy fakt, że jest najmniej przekombinowana. Nie szła w kierunku subtelnych analiz tekstowych (zmierzających przeważnie do wykazania, że przekaz mówi coś innego niż to, co widać w nim na pierwszy rzut oka), lecz starała się znaleźć najprostsze z możliwych wyjaśnienie zagadki. Są też jednak istotne racje merytoryczne.

Po pierwsze, chodzi o istotę trybutu. Zagadnienie to najpełniej opracował M.Z. Jedlicki ${ }^{32}$. Zestawił on ogromny materiał i wyróżnił osiem rodzajów stosunków trybutarnych. Związany jednak aksjomatycznym założeniem, że wzmianka o Warcie musi oznaczać jakiś wewnętrzny podział szerszego terytorium, nie docenił podstawowej okoliczności, iż wczesnośredniowieczne trybuty nakładane były w zasadzie zawsze na władcę lub plemię i ciążyły w związku z tym na całym jego terytorium ${ }^{33}$. Było to oczywiste z różnych względów: danina stawała się powinnością władcy/plemienia i odliczano ją z ich ogólnych dochodów, nie było zaś nawet technicznych możliwości wydzielenia części płynącej z jakiegoś

${ }^{29}$ G. von Grawert-May, Das staatsrechtliche Verhältnis Schlesiens zu Polen, Böhmen und dem Reich während des Mittelalters (Anfang des 10. Jahrhunderts bis 1526), Aalen 1971, s. 30-32.

${ }^{30}$ Zob. jej recenzję pióra G. Labudy, Sobótka 28, 1973, 1, s. 103-107.

${ }^{31} \mathrm{~J}$. Sochacki, Stosunki publicznoprawne między państwem polskim a Cesarstwem Rzymskim w latach 963-1102, Gdańsk 2003, s. 55-56; zob. G. Labuda, O stosunkach prawno-politycznych państwa polskiego z państwem niemieckim w Xi XI wieku, CPH 57, 2005, 1, s. 342, który uznał pogląd Sochackiego w tej sprawie za "całkowicie sprzeczny z wymową źródła”. Krytycznie o hipotezie Grawerta-Maya wypowiedział się E. Rymar (op. cit., s. 210-211), ale najwyraźniej nie zrozumiał jego argumentacji.

${ }^{32}$ M.Z. Jedlicki, op. cit., s. 58-119.

33 Mocno podkreślali to zawsze autorzy niemieccy: G. Sappok, Die Anfänge, s. 29-33; idem, Polens Tributpflicht, s. 266; H. Ludat, Die Anfänge, s. 33-35; G. von Grawert-May, op. cit., s. 18-21. 
wyodrębnionego terytorium cząstkowego. W całym wykorzystanym ogromnym materiale źródłowym Jedlicki wskazał tylko dwa przykłady, kiedy trybut ciążył na części obszaru danego państwa, a powstawał $z$ tytułu nabycia danego terytorium. Pierwszym jest trybut płacony Czechom przez Polskę od 1054 r. z tytułu posiadania Śląska, drugim zaś opłata ustanowiona w 1266 r. przy okazji przejęcia wyspy Man przez Norwegów $^{34}$. Ten drugi należy już do innej epoki i zbliża się do zaczerpniętej z prawa prywatnego formy czynszu z konkretnej nieruchomości. Trudniejszy do wyjaśnienia jest przypadek śląski. I tu można jednak domniemywać, że ustanawiający tę daninę cesarz Henryk III potraktował Śląsk jako odrębne władztwo (przypomina się „regnum ablatum”), z którego (jako całości) Piastowie winni opłacać się Czechom. Charakterystyczne są zresztą dalsze losy tego trybutu, który w następnych pokoleniach zaczęto traktować jako dotyczący całej Polski ${ }^{35}$. Sto lat później, w przywileju Fryderyka Barbarossy dla króla czeskiego Władysława z 1158 r. mowa jest już o „census de terra Polonię" ${ }^{36}$. Widać, że dla ówczesnych ludzi trybut płacony przez władcę w oczywisty sposób traktowany był jako opłata z jego całego państwa. Wydaje się całkowicie nieprawdopodobne, aby w przypadku Mieszka I wypracowano bezprecedensową konstrukcję prawną, zakładającą opłacanie trybutu ze ściśle określonej części jego władztwa.

Po drugie, chodzi o sprawę wyboru punktu odniesienia. Większość zajmujących się sprawą badaczy była zgodna, że słowa „aż do rzeki Warty" rozumieć trzeba z pozycji ich autora, siedzącego w Merseburgu biskupa Thietmara ${ }^{37}$. Patrzeć trzeba więc od zachodu. Tylko niektórzy zwolennicy hipotezy pomorskiej uważali ten wymóg za „śmieszny” (J. Widajewicz), a ze swej strony twierdzili, że patrzeć trzeba z perspektywy cedyńskiego pola bitwy (Zygmunt Wojciechowski) ${ }^{38}$. To podejście absurdalne. Nie dostrzegano natomiast dotąd (poza G. Sappokiem i G. von Grawertem-Mayem), że jest jeszcze jedno rozwiązanie, i to najbardziej

${ }^{34}$ M.Z. Jedlicki, op. cit., s. 79-81.

35 L. Reitinger, „Census de terra Polonie” a premyslovská svrchovanost nad Polskem, „Časopis Matice moravské” 128, 2009, s. 473-492; idem, „Tributum olim duce Bracizlao constitutum". Di̊vod premyslovské svrchovanosti nad Polskem?, w: Trzecie polsko-czeskie forum młodych mediewistów. Commemoratio praeteritorum - społeczności średniowieczne wobec przeszłości, red. H. Krzyżostoniak, J. Kujawiński, M. Matla, Poznań 2012, s. 185-219.

${ }^{36}$ Codex diplomaticus et epistolaris Regni Bohemiae, t. 1, wyd. G. Friedrich, Pragae 1904-1907, nr 180.

${ }^{37}$ G. Labuda, Studia, s. 144-145.

${ }^{38}$ J. Widajewicz, rec.: Herbert Ludat, Mieszkos Tributpflicht bis zur Warthe, „Deutches Archiv für Landes- und Volksforschung” 2, 1938, KH 52, 1938, s. 448; Z. Wojciechowski, Mieszko I i powstanie państwa polskiego, Toruń 1936 (odbitka z „Zapisek Towarzystwa Naukowego Toruńskiego" 1935), s. 25-26. 
naturalne: rozumienie z pozycji podmiotu działającego, a więc księcia Mieszka. Jeżeli Mieszko płacił trybut „po Wartę”, to widzieć tu powinniśmy obszar sięgający od centrum jego władztwa aż po tę rzekę. Przy takim ujęciu chodzić musi oczywiście o całość podległego mu terytorium, Warta zaś gra rolę jego rubieży zewnętrznej, a nie granicy jakiegoś podziału wewnętrznego.

Rodzi się oczywiście pytanie, na którym odcinku Warta pełniła ową graniczną funkcję. Teoretycznie można założyć, że chodzić tu miało o jej płynący południkowo odcinek poznański między Śremem a Obornikami. Zamykał on bowiem od zachodu trzon najstarszego władztwa pierwszych Piastów, ale wcześniej został przez nich przekroczony. Władza Mieszka rozciągała się już na pewno bardziej ku zachodowi, pewnie sięgając Odry. O wiele bardziej prawdopodobne jest, że wzmianka Thietmara odnosi się do równoleżnikowego odcinka Warty poniżej Obornik, do Santoka, a może nawet i dalej, do samego ujścia do Odry (pomijając w tej chwili zaznaczone już wyżej wątpliwości co do nazywania tego fragmentu mianem Noteci). W świetle obowiązującej obecnie wizji władztwa Mieszkowego, opartej głównie na ustaleniach archeologicznych, Warta jawi się nam jako właściwa granica północna. Budowane już w tym czasie grody nad Notecią (z Santokiem na czele) stanowiły tylko wysuniętą rubież obronną od strony Pomorza ${ }^{39}$.

Po trzecie wreszcie, rozwiązanie takie znakomicie wyjaśnia intencję Thietmara. Jeżeli Warta była północną granicą piastowskiego władztwa, Mieszko wykroczył poza jego zasięg. Pominąć tu musimy sporną również kwestię identyfikacji miejsca opisanej bitwy, określonego jako „Cidini”. Przyjmowana najczęściej jego identyfikacja z nadodrzańską Cedynią nie jest bynajmniej oczywista, a są ważkie racje przemawiające przeciwko niej ${ }^{40}$. Niezależnie jednak od sprawy lokalizacji pola walki panuje zgoda,

${ }^{39}$ M. Kara, Najstarsze państwo Piastów - rezultat przełomu czy kontynuacji? Studium archeologiczne, Poznań 2009; Z. Kurnatowska, M. Kara, Wczesnopiastowskie regnum - jak powstało i jaki miało charakter? Próba spojrzenia od strony źródeł archeologicznych, „Slavia Antiqua" 51, 2010, s. 23-85. Na ok. 967 r. datowana jest przebudowa Santoka (Z. Kurnatowska, Grody santockie w świetle dotychczasowych badań archeologicznych, w: Santok - początki grodu. Materiały z sesji historycznej, Gorzów Wlkp. 1995, s. 10-21). Pomijam kwestię, czy Mieszko kontrolował cały obszar władztwa piastowskiego, liczyć się bowiem można $\mathrm{z}$ istnieniem jakichś wewnętrznych podziałów dynastycznych (O. Kossmann, Polen im Mittelalter, t. 2, Marburg 1985, s. 86; D.A. Sikorski, Kościół w Polsce za Mieszka I i Bolesława Chrobrego. Rozważania nad granicami poznania historycznego, Poznań 2011, s. 204-206). Są one jednak zupełnie nieznane, a kontekst polityczny wypowiedzi Thietmara wskazuje jednak wyraźnie, że Warta gra tu rolę granicy zewnętrznej.

${ }^{40} \mathrm{Ch}$. Lübke, Regesten zur Geschichte der Slaven an Elbe und Oder (von Jahr 900 an), t. 2, Berlin 1985, s. 226-228; J.M. Piskorski, op. cit., s. 75-79; P. Migdalski, Znaczenie 
że istotą konfliktu Hodona z Mieszkiem była rywalizacja na Pomorzu, a margrabia próbował przeciwstawić się piastowskiej ekspansji w tym kierunku ${ }^{41}$. W tym kontekście wzmianka o trybucie płaconym aż do Warty staje się w pełni zrozumiała i kluczowa dla całej narracji. Mieszko był wprawdzie wierny cesarzowi i płacił posłusznie trybut, ale wdzierając się na Pomorze, przekroczył wyznaczone sobie granice. Komentarz ten był konieczny, aby czytelnik we właściwym świetle zobaczył postępowanie Hodona, który miał prawo zareagować na samowolę piastowskiego księcia. Tylko zakładając, że konflikt rozegrał się na obszarze o przynajmniej niejednoznacznej przynależności, zrozumiemy opisane dalej przez Thietmara głębokie zatroskanie cesarza Ottona sprawą, w której trudno było jednoznacznie wskazać winowajcę i ofiarę ${ }^{42}$, a także jego reakcję na najbliższym zjeździe w Kwedlinburgu (Wielkanoc $973 \mathrm{r}$.), gdzie obie strony zatargu zostały przyjęte ponownie do łaski monarszej, choć Mieszko musiał dać syna jako zakładnika swej dalszej wierności ${ }^{43}$.

Przyjmując takie rozumienie przekazu, otrzymujemy zarazem także wyjaśnienie istoty Mieszkowego trybutu. Jeżeli Thietmar wspominał o nim, aby pokazać, że Mieszko wykroczył poza zakreślone sobie granice, poza którymi margrabia miał prawo go zaczepiać, oznacza to, że mamy najpewniej do czynienia z trybutem płaconym jako okup za gwarancję bezpieczeństwa. W świetle typologii M.Z. Jedlickiego była to najbardziej podstawowa forma trybutu ${ }^{44}$. To hipotetyczne ustalenie ma znaczenie dla rozwiązania kwestii ustanowienia tego zobowiązania. Istotny jest też stwierdzony przez nas fakt, że trybut dotyczył całego władztwa. Słusznie G. Labuda zauważał kiedyś, że to właśnie cząstkowość trybutu pozwala

i lokalizacja bitwy pod Cidini w świetle historiografii, w: Civitas Schinesghe. Mieszko I i początki państwa polskiego, red. J.M. Piskorski, Poznań-Gniezno 2004, s. 159-169; idem, Bitwa pod Cidini w historiografii, w: Cedynia i okolice poprzez wieki, red. idem, Chojna-Szczecin 2013, s. 37-64; E. Rymar, A jednak pod Cedynia nad Odra w 972 r.?, w: Civitas Cedene. Studia i materiały do dziejów Cedyni, red. P. Migdalski, t. 1, Chojna-Szczecin-Cedynia 2014, s. 125-151.

${ }^{41}$ G. Labuda, Studia, s. 80-129; B. Śliwiński, Pomorze w polityce i strukturze państwa wczesnopiastowskiego (X-XII w.), KH 107, 2000, 2, s. 10-14.

42 „Inperator turbatus de Italia nuncios misit precipientes Hodoni atque Miseconi, si gratiam suimet habere voluissent, usque dum ipse veniens causam discuteret, in pace permanerent", Thietmar, lib. II, cap. 29, s. 76; tłum. pol., s. 92.

${ }^{43}$ Podkreślał to mocno G. Sappok, Polens Tributpflicht, s. 269. Za niesłuszne uważam zatem żale polskich historyków wobec Ottona za stronniczy wyrok, krzywdzący niewinnego w tej sprawie Mieszka (G. Labuda, Studia, s. 125-127); o zjeździe w Kwedlinburgu zob. ibidem, s. 325-341; J. Strzelczyk, op. cit., s. 158-160; ostatnio zbiór: Der Hoftag in Quedlinburg 973. Von den historischen Wurzeln zum Neuen Europa, red. A. Ranft, Berlin 2006.

${ }^{44}$ M.Z. Jedlicki, op. cit., s. 74-77. 
przyjmować jego ustanowienie w toku rokowań o kwestie fiskalne, a więc $i$ jego dobrowolność ${ }^{45}$. Zdjęcie tego warunku zmienia sytuację: trybut był Mieszkowi narzucony.

Początki trybutu płaconego przez Mieszka kojarzyły się badaczom przeważnie z wydarzeniami 963 r., kiedy to margrabia Gero podporządkować miał księcia Mieszka cesarskiej zwierzchności. Pisze o tym Thietmar $^{46}$, ale jego relacja budzi zasadnicze wątpliwości. Wielu badaczy odmawia jej wiarogodności. Stanowisko to sformułował jako pierwszy Kazimierz Tymieniecki, najpełniej rozwinął G. Labuda, a obecnie broni go Tomasz Jasiński ${ }^{47}$. Ich zdaniem relacja Thietmara (piszącego w drugim dziesięcioleciu XI w.) powstała poprzez przeinaczenie odpowiedniego ustępu z wcześniejszej (ok. 968) kroniki Widukinda z Korvei. Obszerny wywód, w którym Widukind opisywał stosunki margrabiego Gerona z saskim banitą Wichmanem, ucieczkę tego ostatniego do Wieletów i jego zwycięskie walki z Mieszkiem, a także przewagi Gerona nad słowiańskimi Łużyczanami ${ }^{48}$, Thietmar drastycznie skrócił, ale nie zrozumiał go poprawnie i całkowicie wypaczył jego sens. Wszystkie zwycięstwa przypisał Geronowi i tak powstała opowieść, że to ten margrabia podbił zarówno Łużyczan, jak i Mieszka. Całkowite deprecjonowanie przekazu Thietmara nie wydaje się jednak właściwe ${ }^{49}$. Na pewno korzystał on

${ }^{45}$ G. Labuda, Studia, s. 159.

46 „Gero Orientalium marchio Lusizi et Selpuli, Miseconem quoque cum sibi subiectis imperiali subdidit dicioni”, Thietmar, lib. II, cap. 14, s. 54; tłum. pol., s. 58.

${ }^{47}$ K. Tymieniecki, Widukind i Thietmar o wypadkach z roku 963, RH 12, 1936, s. 95-106; G. Labuda, Studia, s. 5-54; idem, Mieszko I, s. 72-81; idem, Pierwsze wieki, s. 38 n.; T. Jasiński, Czy państwo polskie za Mieszka I było suwerenne?, „Studia nad Dawną Polską” 2, 2009, s. 9-19; idem, Początki organizacji kościelnej w Polsce, w: Tu się wszystko zaczęło. Rola Poznania w państwie pierwszych Piastów, red. A. Wójtowicz, Poznań 2010, s. 87-94.

${ }^{48}$ "Gero igitur comes non inmemor iuramenti, cum Wichmannum accusari vidisset reumque cognovisset, barbaris, a quibus eum assumpsit, restituit. Ab eis libenter susceptus longius degentes barbaros crebris preliis contrivit, Misacam regem, cuius potestatis erant Sclavi, qui dicuntur Licicaviki, duabus preliis superavit fratremque ipsius interfecit, predam magnam ab eo extorsit", Die Sachsengeschichte des Widukind von Korvei, wyd. H.-E. Lohmann, P. Hirsch, Hannover 1935, MGH SrG, t. [60] (dalej: Widukind), lib. III, cap. 66, s. 141; „Gero preses Sclavos, qui dicuntur Lusiki, potentissime vicit et ad ultimam servitutem coegit, non sine sui tamen gravi vulnere nepotisque optimi viri casu, ceterorum quoque quam plurimorum nobilium virorum", lib. III, cap. 67 , s. 141-142.

${ }^{49}$ Istnieje też jednak drugi obóz, który nie odrzuca relacji Thietmara, zob. M.Z. Jedlicki, op. cit., s. 20-27; H. Łowmiański, Początki, t. 5, s. 517-521; J. Strzelczyk, op. cit., s. 81-93; J. Sochacki, op. cit., s. 55; S. Rosik, Poczatki Polski w kronikach niemieckich X-XI w. (w kręgu wiadomości Widukinda z Korwei), w: Kolory i struktury średniowiecza, red. W. Fałkowski, Warszawa 2004, s. 236-240; D.A. Sikorski, O stosunkach polsko-niemieckich 
z Widukinda, ale nie sposób jednak udowodnić, że jego własna relacja powstała wyłącznie na podstawie wiadomości od niego zaczerpniętych, a potem nieumiejętnie zmontowanych. Przede wszystkim obaj kronikarze układali relacje o różnych sprawach: dla Widukinda głównym bohaterem był Wichman, a czyny Gerona traktowane są ubocznie, Thietmarowi chodziło tylko o krótką informację o postępach panowania saskiego, a Wichmanem nie interesował się wcale. Różnice nie muszą wynikać $\mathrm{z}$ błędnego zrozumienia, ale z różnego rozłożenia priorytetów narracyjnych. Thietmar miał $w$ dodatku dowodnie pewne nadwyżki informacyjne w stosunku do swego poprzednika. O ile Widukind pisze, że Gero podbił Łużyczan, o tyle u Thietmara pada też druga nazwa plemienna: „Selpuli", siedzący gdzieś w okolicy ujścia Nysy Łużyckiej do Odry ${ }^{50}$. Widać więc, że Thietmar wiedział o sprawie więcej, niż wyczytał u Widukinda, a więc może i w sprawie Mieszka podawał fakty, których poprzednik nie uznał za stosowne zapisać. Nie do utrzymania są także argumenty pomocnicze, jakie wytaczano przeciwko wiarogodności Thietmara. Wskazywano, że Gero nie miał interesu w atakowaniu Mieszka, skoro ten walczył jednocześnie z groźnymi dla Sasów Wieletami. To prawda, ale odpowiedzieć można, że przecież w interesie margrabiego leżało też wykorzystanie osłabienia piastowskiego księcia klęskami zadanymi przez Wichmana (i nie trzeba wcale uciekać się do mętnych podejrzeń o tajne konszachty między tym ostatnim a Geronem) ${ }^{51}$. Zostając zaś przy obserwacji kontekstu politycznego, zauważmy jeszcze podnoszoną niekiedy sprzeczność między zobowiązaniem trybutarnym, o którym pisze pod $972 \mathrm{r}$. Thietmar, a zaszczytnym mianem ,przyjaciela cesarza”, jakie Mieszkowi przydaje Widukind w narracji o wypadkach z $967 \mathrm{r}^{52}$ Sprzeczność może być pozorna, bo polityczna „przyjaźn” bywała w tamtych

w X i XI wieku, „Studia Historica Slavo-Germanica” 26, 2004/2005 (wyd. 2006), s. 263-266 (ze zreferowaniem badań nad narastaniem przekazu Widukinda i sugestią, że rozdz. III 66 w swej pierwotnej wersji mógł relacjonować zwycięstwa Gerona nad Mieszkiem); należy tu także zasadniczo historiografia niemiecka: H. Ludat, Die Anfänge, s. 26; A. Angenendt, op. cit., s. 296-297; Ch. Lübke, Regesten, t. 2, s. 170-171; idem, Das östliche Europa, s. 189; J. Fried, op. cit., s. 635; H. Keller, G. Althoff, op. cit., s. 236.

50 G. Labuda, Selpuli, SSS, t. 5, red. W. Kowalenko, G. Labuda, T. Lehr-Spławiński, Wrocław 1975, s. 128, a ostatnio J. Nalepa, Granice Polski najdawniejszej. Prolegomena, t. 1, Kraków 1996, s. 130-144 (który umieszcza to plemię w kolanie Sprewy).

${ }^{51}$ Zob. P. Urbańczyk, Mieszko Pierwszy tajemniczy, Toruń 2012, s. 319-320.

52 Widukind, lib. III, cap. 69, s. 144 („Misacam amicum imperatoris bello lascesserent”), s. 145 („Accipe, inquit, hunc gladium et defer domino tuo, quo pro signo victoriae illum teneat imperatorique amico transmittat"). Ważne jest, że nie tylko Mieszko był przyjacielem cesarza, ale i cesarz - przyjacielem Mieszka. O politycznej „przyjaźni” zob. S. Rosik, op. cit., s. 241-247, 251-252. 
czasach często formą realizacji interesów mocarstwowych, a pojedyncze użycie predykatu „amicus imperatoris” widzieć trzeba nie tyle w kontekście politycznym, ile przede wszystkim narracyjnym (grał u Widukinda istotną rolę w budowaniu napięcia fabularnego opowieści o losach Wichmana) ${ }^{53}$. Jeśli już chcielibyśmy ją wyjaśniać, to przyjąć trzeba, że trybut (jako forma ostrzejsza) musiał poprzedzać ustanowienie przyjaźni, które kłaść należy na lata 965-966 i wiązać z chrztem piastowskiego księcia ${ }^{54}$. Zobowiązanie trybutarne musiało zatem nastąpić przed $965 \mathrm{r}$., ale trudno cofać je zbyt daleko w czasie, skoro Piastowie nie mieli wcześniej stosunków z Sasami. W rozumowanie to znakomicie wpisałoby się ustanowienie trybutu w $963 \mathrm{r}$.

Dla rekonstrukcji wypadków musimy więc uwzględnić, jako niezależne, trzy przekazy: Widukinda, Thietmara oraz tzw. Kontynuację Reginona $^{55}$ (pisaną niemal współcześnie przez Adalberta z Trewiru, późniejszego arcybiskupa magdeburskiego). Ponieważ Widukind i Adalbert piszą tylko o podboju Łużyczan przez Gerona, a Thietmar o podporządkowaniu Łużyczan, „Selpuli” i Mieszka, przekazy uzgodnić można w następujący sposób: Gero rzeczywiście pobił wtedy Łużyczan (a może i drugie z podanych plemion, którego inni obserwatorzy mogli nie zauważyć), z Mieszkiem natomiast nie walczył (skoro Widukind i Adalbert nie uznali za stosowne o tym wspomnieć) ${ }^{56}$, ale przyjął go pod cesarskie zwierzchnictwo (co z perspektywy czasu docenił Thietmar). Jak to w praktyce wyglądało, pozwala nam wyobrazić sobie relacja Widukinda o poselstwie słowiańskim do Ottona przed bitwą nad Reknicą w $955 \mathrm{r}$. Zagrożeni najazdem Słowianie zaproponowali wtedy królowi w zamian za wstrzymanie kroków wojennych zgodne ze zwyczajem płacenie mu trybutu w charakterze sojuszników ${ }^{57}$. Wtrącona tu wzmianka o „zwy-

${ }^{53}$ A. Pleszczyński, op. cit., s. 43-63; por. też J. Fried, op. cit., s. 601, który podkreśla wyjątkowość kategorii „przyjaciela” w strukturze ottońskiej Rzeszy.

${ }^{54}$ G. Labuda, Studia, s. 140, łączył trybut z zawarciem przyjaźni i kładł je razem na 965-966 r., z czym do pewnego stopnia (pomijając kwestię trybutu) można się zgodzić (zob. niżej, przyp. 62).

55 „apud nos quoque Sclavi, qui dicuntur Lusizani, subduntur”, Reginonis abbatis Prumensis Chronicon cum continuatione Treverensi, wyd. F. Kurze, Hannoverae 1890, MGH SrG, t. [50], s. 173 (pod 963 r., co wyznacza nam datę wydarzeń, której nie podają Widukind i Thietmar).

${ }^{56}$ Historycy niemieccy powtarzają przeważnie wiadomość o militarnym zwycięstwie Gerona (zob. wyżej, przyp. 7, 27 i 49).

57 „Aderat et legatio barbarorum tributa socios ex more velle persolvere nuntians, caeterum dominationem regionis velle tenere; hoc pacto pacem velle, alioquin pro libertate armis certare", Widukind, lib. III, cap. 53, s. 132; zob. M.Z. Jedlicki, op. cit., s. 104-106. 
czaju" każe uznać, że była to często stosowana praktyka. Odwołać się do niej mógł także Mieszko. Łatwo zrozumieć jego ówczesne zachowanie. Po klęskach, jakie poniósł świeżo z rąk prowadzonych przez Wichmana Wieletów (przegrał dwie bitwy i stracił w nich brata) ${ }^{58}$, obawiać się mógł kolejnego najazdu grożącego od zachodu (Gero doszedł już do Odry) i za cenę sprawdzonej formy trybutu kupił sobie spokój od tej strony ${ }^{59}$. Margrabia, którego kampania łużycka wiele kosztowała (miał w niej odnieść ciężką ranę i stracić wielu ludzi, w tym własnego bratanka), ochoczo przyjął na pewno ofertę. Dalszym elementem tej samej polityki Mieszka było zawarcie sojuszu z Czechami i ślub z Dobrawą (może już w tym samym 963 r. $)^{60}$. Konsekwencją wejścia na drogę kontaktów z chrześcijańskimi potęgami była zaś z kolei decyzja o przyjęciu chrztu, może rzeczywiście podjęta nie bez znaczącego wpływu wspomnianej żony, której rola w ujęciu Thietmara odbiega od tradycyjnego toposu „mulier suadens" ${ }^{61}$. Sprawa konwersji piastowskiego księcia najprawdopodobniej załatwiana była przy pośrednictwie cesarza Ottona. Domniemane spotkanie z nim na wielkim zjeździe w Magdeburgu wiosną 965 r. wydaje się najlepszą okazją do ustanowienia wspomnianej „przyjaźni”, cokolwiek by ona miała oznaczaćc ${ }^{6}$.

58 G. Labuda (Studia, s. 41-54) starał się dowodzić, że walki Mieszka z Wieletami miały miejsce nieco później (964-965), ale jego argumenty nie są przekonujące i nie są w stanie osłabić wymowy Widukinda, który wyraźnie sugeruje współczesność tych wypadków z łużycką kampanią Gerona.

${ }_{59}$ Podobnie już J. Widajewicz, Licicaviki, s. 149-150, potem zaś także J. Strzelczyk, op. cit., s. 91-92; J. Sochacki, op. cit., s. 55. Natomiast H. Łowmiański (Początki, t. 5, s. 526-527) zakładał zbrojny atak Gerona na Mieszka, dokonany jednak najwcześniej zimą 963/964 r., a więc bez związku z kampanią łużycką (zima 962/963); konstrukcja taka nie da się utrzymać, skoro źródła wskazują na jednoczesność podporządkowania Łużyczan i Mieszka, a po odbyciu jesienią 963 r. pielgrzymki do Rzymu, gdzie symbolicznie złożył „arma victricia” przed grobem św. Piotra, Gero poświęcił się już wyłącznie dziełom religijnym (,emeritus iam senex [--] ad Deum cum omni suimet hereditate confugit", Thietmar, lib. II, cap. 19, s. 60; tłum. pol., s. 68-70).

${ }^{60}$ Thietmar (lib. IV, cap. 56, s. 194; tłum. pol., s. 220) wspomina o tych, którzy mówią, że Dobrawa trzykrotnie łamała Wielki Post, co mogłoby odpowiadać datowaniu małżeństwa z Mieszkiem na 963 r., oczywiście przy założeniu, że uwzględnimy także Wielki Post $966 \mathrm{r}$.

${ }^{61}$ J. Banaszkiewicz, Dąbrówka „christianissima” i Mieszko poganin (Thietmar, IV, 55-56; Gall, I, 5-6), w: Nihil superfluum esse. Studia z dziejów średniowiecza ofiarowane profesor Jadwidze Krzyżaniakowej, red. J. Strzelczyk, J. Dobosz, Poznań 2000, s. 85-93; P. Wiszewski, Domus Bolezlai. W poszukiwaniu tradycji dynastycznej Piastów (do około 1138 roku), Wrocław 2008, s. 199-202, 576-579.

${ }^{62}$ Zob. T. Jurek, O czasie i okolicznościach chrztu Mieszka, RH 81, 2015, s. 35-56. 


\section{Streszczenie}

Artykuł dotyczy zagadnienia stosunków najstarszego władztwa piastowskiego w X w. do cesarstwa Ottonów. Saski kronikarz Thietmar z Merseburga w swej relacji o bitwie stoczonej w 972 r. przez polskiego księcia Mieszka I z saskim margrabią Hodonem napisał (lib. II, cap. 29), że Mieszko był „wierny cesarzowi i płacił mu trybut aż do rzeki Warty” (,inperatori fidelis tributumque usque in Vurta fluvium solvens"). Zdanie to było od dawna przedmiotem sprzecznych interpretacji. Historycy niemieccy przyjmują przeważnie, że chodzi o całą zachodnią część władztwa piastowskiego (patrząc od zachodu). Historycy polscy natomiast próbowali zawsze zminimalizować znaczenie trybutu i wykazywali w związku z tym, że chodziło o jakieś cząstkowe terytorium, przy czym przeważnie wskazywano Pomorze (które leżało jednak już za Wartą) lub niewielki obszar domniemanego plemienia Lubuszan (u ujścia Warty do Odry). Autor artykułu, nawiązując do pomysłów niektórych historyków niemieckich, stara się dowieść, że dla właściwego zrozumienia rozważanego zdania trzeba je interpretować z punktu widzenia Mieszka. Chodziło zatem o całość jego władztwa, patrząc od jego centrum do Warty, i.e. rzeki pełniącej tu rolę granicy zewnętrznej. Na rzecz takiej wykładni świadczy fakt, że trybuty nakładano wówczas z zasady na całe państwa lub ludy, nie zaś na ich sztucznie wyodrębnione części. Warta rzeczywiście stanowiła orientacyjną granicę dzielącą władztwo Piastów od Pomorza. Proponowana interpretacja znakomicie pasuje do kontekstu relacji Thietmara. Tło starcia Mieszka z Hodonem stanowiła ekspansja polska na Pomorze. Komentarz, że Mieszko płacił trybut z terytorium do granicznej Warty, służył wyjaśnieniu, że Hodo miał prawo zaatakować wiernego cesarzowi księcia, skoro ten wykroczył poza wskazaną granicę. Stosunek trybutarny nawiązany został zapewne w 963 r., kiedy to (zgodnie z relacją Thietmara, którą historycy polscy często kwestionują) margrabia Gero narzucił Mieszkowi cesarskie zwierzchnictwo. Można to sobie wyobrazić w ten sposób, że gdy Gero po zwycięstwach nad Łużyczanami zbliżał się do Odry, zaniepokojony Mieszko sam mu się poddał i zaoferował trybut.

\section{“Usque in Vurta fluvium”. On Mieszko's Tribute}

The article is about relations between the oldest Piast rulers (tenth century) and the Ottonian Empire. In his account of the battle waged in 972 by the Polish Duke Mieszko I and the Saxon Margrave Hodo, the Saxon chronicler Thietmar of Merseburg wrote (II, 29) that Mieszko was "loyal to the emperor and paid him a tribute all the way to the river Warta" (inperatori fidelis tributumque usque in Vurta fluvium solvens). This sentence has been for long the object of contradictory interpretations. As a rule, German historians maintain that it refers to the entire Western part of the Piast dominion (looking from the West). On the other hand, Polish historians always attempted to minimalize the significance of the tribute and consequently indicated that the chronicler had in mind a certain fragmentary territory; as a rule, they pointed to Pomerania (which, however, was located already beyond the Warta) 
or a small region of the supposed Lubuszanie tribe (at the mouth of the Warta flowing into the Odra). By referring to conceptions launched by certain German historians the author of the article tries to prove that a proper comprehension of the examined sentence calls for its interpretation from the viewpoint of Mieszko. In other words, it pertains to his whole dominion, seen from its centre towards the Warta, i.e. a river playing the part of an outer frontier. Such an interpretation is supported by the fact that at the time tributes were, as a rule, imposed on a whole state or a people and not their artificially distinguished parts. True, the Warta did constitute a rough boundary separating the Piast state from Pomerania. The proposed approach matches the context of the Thietmar account. The background of the clash between Mieszko and Hodo was Polish expansion in Pomerania. The commentary claiming that Mieszko paid a tribute from a territory up to Warta, a frontier river, was used to explain that Hodo was entitled to attack a duke loyal to the emperor since the former had crossed the boundary. The tribute-based relation was established probably in 963 when (according to Thietmar's account, often questioned by Polish historians), margrave Gero imposed imperial supremacy over Mieszko I. Presumably, when after a victory over the Lusatians Gero moved towards the Odra, alarmed Mieszko voluntarily surrendered and offered a tribute.

Translated by Aleksandra Rodzińska-Chojnowska

\section{Bibliografia}

Angenendt, Arnold. Kaiserherrschaft und Königstaufe. Kaiser, Könige und Päpste als geistliche Patrone in der abendländischen Missionsgeschichte. Berlin: Walter de Gruyter, 1984.

Baethgen, Friedrich. „Zur Geschichte der ältesten deutsch-polnischen Beziehungen”. Altpreußische Forschungen 13 (1936): 1-16.

Banaszkiewicz, Jacek. „Dąbrówka «christianissima» i Mieszko poganin (Thietmar, IV, 55-56; Gall, I, 5-6)". W Nihil superfluum esse. Studia z dziejów średniowiecza ofiarowane profesor Jadwidze Krzyżaniakowej, red. Jerzy Strzelczyk, Józef Dobosz, 85-93. Poznań: Instytut Historii Uniwersytetu im. Adama Mickiewicza, 2000.

Bandtkie, Jan Samuel. Dzieje narodu polskiego. T. 1. Wrocław: Wilhelm Bogumił Korn, 1835.

Barthold, Friedrich Wilhelm. Geschichte von Rügen und Pommern. T. 1. Hamburg: Friedrich Perthes, 1839.

Bogusławski, Wilhelm. Dzieje Słowiańszczyzny Pótnocno-Zachodniej do połowy XIII w. T. 3. Poznań: nakładem autora, 1892.

Dowiat, Jerzy. Metryka chrztu Mieszka I i jej geneza. Warszawa: Państwowe Wydawnictwo Naukowe, 1961.

Fried, Johannes. Der Weg in die Geschichte. Die Ursprünge Deutschlands bis 1024. Berlin: Ullstein, 1998.

Grawert-May, Gernot von. Das staatsrechtliche Verhältnis Schlesiens zu Polen, Böhmen und dem Reich während des Mittelalters (Anfang des 10. Jahrhunderts bis 1526). Aalen: Scientia Verlag, 1971. 
Grodecki Roman, Stanisław Zachorowski, Jan Dąbrowski. Dzieje Polski średniowiecznej. 1926. Wyd. 2. Kraków: Universitas, 1995.

Holtzmann, Robert. Geschichte der sächsischen Kaiserzeit (900-1024). München: Verlag Georg D.W. Callwey, 1941.

Jasiński, Tomasz. „Czy państwo polskie za Mieszka I było suwerenne?”. Studia nad Dawną Polska 2 (2009): 9-19.

Jasiński, Tomasz. „Początki organizacji kościelnej w Polsce”. W Tu się wszystko zaczęło. Rola Poznania w państwie pierwszych Piastów, red. Andrzej Wójtowicz, 87-94. Poznań: Instytut Chemii Bioorganicznej PAN, Ośrodek Wydawnictw Naukowych, 2010.

Jaworski, Krzysztof. „Pobarane - Bobrzanie czy Obrzanie?”. W Viae historicae. Księga jubileuszowa dedykowana Profesorowi Lechowi A. Tyszkiewiczowi w siedemdziesiątą rocznicę urodzin, red. Mateusz Goliński, Stanisław Rosik, 178-188. Wrocław: Wydawnictwo Uniwersytetu Wrocławskiego, 2001.

Jedlicki, Marian Zygmunt. Stosunek prawny Polski do Cesarstwa do r. 1000. Poznań: Poznańskie Towarzystwo Przyjaciół Nauk, 1939.

Jurek, Tomasz. „O czasie i okolicznościach chrztu Mieszka”. Roczniki Historyczne 81 (2015): 35-56.

Kara, Michał. Najstarsze państwo Piastów - rezultat przełomu czy kontynuacji? Studium archeologiczne. Poznań: Instytut Archeologii i Etnologii PAN, 2009.

Keller, Hagen, Gerd Althoff. Die Zeit der späten Karolinger und der Ottonen. Krisen und Konsolidierungen 888-1024. Gebhardt. Handbuch der deutschen Geschichte. Wyd. 10. T. 3. Stuttgart: Klett-Cotta, 2008.

Kiersnowski, Ryszard. „Lubuszanie”. W Słownik starożytności słowiańskich. T. 3, cz. 1, red. Władysław Kowalenko, Gerard Labuda, Zdzisław Stieber, 101. Wrocław: Zakład Narodowy imienia Ossolińskich, Wydawnictwo PAN, 1967.

Köpke, Rudolf, Ernst Dümmler. Kaiser Otto der Große. Jahrbücher der deutschen Geschichte. Leipzig: Verlag von Duncker \& Humblot, 1876.

Kossmann, Oskar. Polen im Mittelalter. T. 2. Marburg: J.G. Herder-Institut, 1985.

Kowalczyk, Elżbieta. „Momenty geograficzne państwa Bolesława Chrobrego. Na styku historii i archeologii”. Kwartalnik Historyczny 107, 2 (2000): 68-73.

Kurnatowska, Zofia. „Grody santockie w świetle dotychczasowych badań archeologicznych". W Santok - początki grodu. Materiały z sesji historycznej, 10-21. Gorzów: Towarzystwo Przyjaciół Archiwum i Pamiątek Przeszłości, 1995.

Kurnatowska, Zofia, Michał Kara. „Wczesnopiastowskie regnum - jak powstało i jaki miało charakter? Próba spojrzenia od strony źródeł archeologicznych". Slavia Antiqua 51 (2010): 23-85.

Labuda, Gerard. Fragmenty dziejów Słowiańszczyzny Zachodniej. T. 1. Poznań: Wydawnictwo Poznańskie, 1960.

Labuda, Gerard. „Licicaviki”. W Słownik starożytności słowiańskich. T. 3, cz. 1, red. Władysław Kowalenko, Gerard Labuda, Zdzisław Stieber, 56. Wrocław: Zakład Narodowy imienia Ossolińskich, Wydawnictwo PAN, 1967.

Labuda, Gerard. Mieszko I. Wrocław: Zakład Narodowy imienia Ossolińskich, Wydawnictwo, 2002.

Labuda, Gerard. „O stosunkach prawno-politycznych państwa polskiego z państwem niemieckim w X i XI wieku". Czasopismo Prawno-Historyczne 57, nr 1 (2005): 327-378. 
Labuda, Gerard. Pierwsze wieki monarchii piastowskiej. Poznań: Wydawnictwo Nauka i Innowacje, 2012.

Labuda, Gerard. „Selpuli”. W Słownik starożytności słowiańskich. T. 5, red. Władysław Kowalenko, Gerard Labuda, Tadeusz Lehr-Spławiński, 128. Wrocław: Zakład Narodowy imienia Ossolińskich, Wydawnictwo PAN, 1975.

Labuda, Gerard. Studia nad poczatckami państwa polskiego. Poznań: Księgarnia Akademicka, 1946. Wyd. 2. 2 t. Poznań: Wydawnictwo Naukowe Uniwersytetu im. Adama Mickiewicza, 1987-1988.

Lübke, Christian. Das östliche Europa. Die Deutschen und das europäische Mittelalter. München: Siedler, 2004.

Lübke, Christian. Regesten zur Geschichte der Slaven an Elbe und Oder (von Jahr 900 an). T. 2. Berlin: In Kommission bei Dubkewr \& Humblot, 1985.

Ludat, Herbert. Die Anfänge des polnischen Staates. Krakau: Burgverlag Krakau G.m.b.H; Verlag des Instituts für Deutsche Ostarbeit, 1942.

Ludat, Herbert. „Mieszkos Tributpflicht bis zur Warthe”. Deutsches Archiv für Landesund Volksforschung 2 (1938): 380-385.

Ludat, Herbert. „Warthe oder Netze?”, Beiträge zur Namensforschung 3 (1951/1952): 213-221.

Łowmiański, Henryk. „Imię chrzestne Mieszka I”. Slavia Occidentalis 19 (1948): 297-305.

Łowmiański, Henryk. Początki Polski. T. 5. Warszawa: Państwowe Wydawnictwo Naukowe, 1973.

Migdalski, Paweł. „Bitwa pod Cidini w historiografii”. W Cedynia i okolice poprzez wieki, red. Paweł Migdalski, 37-64. Chojna: Stowarzyszenie Historyczno-Kulturalne „Terra Incognita”; Szczecin: Instytut Historii i Stosunków Międzynarodowych Uniwersytetu Szczecińskiego, 2013.

Migdalski, Paweł. „Znaczenie i lokalizacja bitwy pod Cidini w świetle historiografii”. W Civitas Schinesghe. Mieszko I i początki państwa polskiego, red. Jan M. Piskorski, 159-169. Poznań: Ośrodek Wydawnictw Naukowych, PAN; Wydawnictwo Poznańskiego Towarzystwa Przyjaciół Nauk; Gniezno: Muzeum Początków Państwa Polskiego, 2004.

Moździoch, Sławomir. „Śląsk między Gnieznem a Pragą”. W Ziemie polskie w X wieku $i$ ich znaczenie w kształtowaniu się nowej mapy Europy, red. Henryk Samsonowicz. Kraków: 169-198, 2000.

Mühle, Eduard. Die Piasten. Polen im Mittelalter. München: C.H. Beck, 2011.

Myśliński, Kazimierz. Polska wobec Słowian Połabskich do końca wieku XII. Lublin: Wydawnictwo Uniwersytetu Marii Curie-Skłodowskiej, 1993.

Nalepa, Jerzy. Granice Polski najdawniejszej. Prolegomena. T. 1. Kraków: Polska Akademia Umiejętności, 1996.

Piskorski, Jan M. Pomorze plemienne. Historia - archeologia - językoznawstwo. Poznań: Wydawnictwo Sorus; Wydawnictwo Poznańskiego Towarzystwa Przyjaciół Nauk; Szczecin: Muzeum Narodowe, 2002.

Pleszczyński, Andrzej. Niemcy wobec pierwszej monarchii piastowskiej (963-1034). Narodziny stereotypu. Postrzeganie i cywilizacyjna klasyfikacja władców Polski i ich kraju. Lublin: Wydawnictwo Uniwersytetu Marii Curie-Skłodowskiej, 2008.

Pohorecki, Feliks. Recenzja: La création du premier archevêché polonais à Gniezno, Marian Zygmunt Jedlicki. Kwartalnik Historyczny 48 (1934): 140-144. 
Ranft, Andreas, red. Der Hoftag in Quedlinburg 973. Von den historischen Wurzeln zum Neuen Europa. Berlin: Akademie Verlag, 2006.

Reitinger, Lukas. „ «Census de terra Polonie» a přemyslovská svrchovanost nad Polskem". Časopis Matice moravské 128 (2009): 473-492.

Reitinger, Lukas. „«Tributum olim duce Bracizlao constitutum». Důvod přemyslovské svrchovanosti nad Polskem?". W Trzecie polsko-czeskie forum młodych mediewistów. Commemoratio praeteritorum - społeczności średniowieczne wobec przeszłości, red. Hanna Krzyżostoniak, Jakub Kujawiński, Marzena Matla, 185-219. Poznań: Instytut Historii UAM, 2012.

Rosik, Stanisław. „Początki Polski w kronikach niemieckich X-XI w. (w kręgu wiadomości Widukinda z Korwei)". W Kolory i struktury średniowiecza, red. Wojciech Fałkowski, 236-240. Warszawa: Wydawnictwo DiG, 2004.

Rymar, Edward. „A jednak pod Cedynią nad Odrą w 972 r.?”. W Civitas Cedene. Studia i materiały do dziejów Cedyni, red. Paweł Migdalski. T. 1, 125-151. Chojna: Stowarzyszenie Historyczno-Kulturalne „Terra Incognita”; Szczecin: Instytut Historii i Stosunków Międzynarodowych Uniwersytetu Szczecińskiego; Cedynia: Muzeum Regionalne w Cedyni, 2014.

Rymar, Edward. „Terytorium usque in Vurta fluvium, czyli Pomorze obszarem trybutarnym Niemiec za Mieszka I". W Biskupi, lennicy, żeglarze, red. Błażej Śliwiński, 189-228. Gdańskie Studia z Dziejów Średniowiecza 9. Gdańsk: Wydawnictwo Uniwersytetu Gdańskiego; WiM, 2003.

Sappok, Gerhard. Die Anfänge des Bistums Posen und die Reihe seiner Bischöfe von 9681498. Leipzig: Verlag von S. Hirzel, 1937.

Sappok, Gerhard. „Polens Tributpflicht gegenüber dem Deutschen Reiche im 10. Jahrhundert". Deutsches Archiv für Landes- und Volksforschung 5 (1941): 260-270.

Sikorski, Dariusz Andrzej. Kościół w Polsce za Mieszka I i Bolesława Chrobrego. Rozważania nad granicami poznania historycznego. Poznań: Wydawnictwo Naukowe Uniwersytetu im. Adama Mickiewicza, 2011.

Sikorski, Dariusz Andrzej. „O stosunkach polsko-niemieckich w X i XI wieku”. Studia Historica Slavo-Germanica 26 (2004/2005): 263-266.

Sikorski, Dariusz Andrzej. Początki Kościoła w Polsce. Wybrane problemy. Poznań: Wydawnictwo Poznańskiego Towarzystwa Przyjaciół Nauk, 2012.

Słownik historyczno-geograficzny województwa poznańskiego w średniowieczu. Cz. 3, red. Antoni Gąsiorowski. Poznań: Wydawnictwo Poznańskiego Towarzystwa Przyjaciół Nauk, 1993-1999.

Sochacki, Jarosław. Stosunki publicznoprawne między państwem polskim a Cesarstwem Rzymskim w latach 963-1102. Gdańsk: Wydawnictwo Pomorskiej Akademii Pedagogicznej Officina Ferberiana, 2003.

Stasiewski, Bernhard. Die Anfänge der Christianisierung Polens auf dem Hintergrund der slavischen Missionsgeschichte des frühen Mittelalters. Münster: Verlagshaus Monsenstein und Vannerdat OHG, 2014.

Strzelczyk, Jerzy. Mieszko Pierwszy. Poznań: Wydawnictwo Poznańskie, 1992.

Szczur, Stanisław. Historia Polski. Średniowiecze. Kraków: Wydawnictwo Literackie, 2002.

Śliwiński, Błażej. „Pomorze w polityce i strukturze państwa wczesnopiastowskiego (X-XII w.)". Kwartalnik Historyczny 107, 2 (2000): 3-40. 
Tymieniecki, Kazimierz. „Początki państwa Polan”. Przegląd Historyczny 50 (1959): 23-50.

Tymieniecki, Kazimierz. Polska w średniowieczu, Warszawa: Państwowe Wydawnictwo Naukowe, 1961.

Tymieniecki, Kazimierz. Recenzja: Studia nad początkami państwa polskiego, Gerard Labuda. Slavia Occidentalis 19 (1948): 459-471.

Tymieniecki, Kazimierz. „Widukind i Thietmar o wypadkach z roku 963”. Roczniki Historyczne 12 (1936): 95-106.

Urbańczyk, Przemysław. Mieszko Pierwszy tajemniczy. Toruń: Wydawnictwo Naukowe Uniwersytetu Mikołaj Kopernika, 2012.

Widajewicz, Józef. „Licicaviki Widukinda. Studium onomastyczno-geograficzne”. Slavia Occidentalis 6 (1927): 85-182.

Widajewicz, Józef. „Polski obszar trybutarny w X wieku”. Śląski Kwartalnik Historyczny „Sobótka” 2 (1947): 47-92.

Wiszewski, Przemysław. Domus Bolezlai. W poszukiwaniu tradycji dynastycznej Piastów (do około 1138 roku). Wrocław: Wydawnictwo Uniwersytetu Wrocławskiego, 2008.

Wojciechowski, Zygmunt. Mieszko I i powstanie państwa polskiego. Toruń: Towarzystwo Naukowe w Toruniu, 1936.

Wojciechowski, Zygmunt. Polska - Niemcy. Dziesięć wieków zmagania. Poznań: Wydawnictwo Instytutu Zachodniego, 1945.

Wojciechowski, Zygmunt. „Usque in Vurta fluvium”. W Wirtschaft und Kultur. Festschrift zum 70. Geburtstag von Alfons Dopsch, 289-299. Baden bei Wien-Leipzig: R.M. Rohrer Verlag, 1938.

Zakrzewski, Stanisław. Mieszko I jako budowniczy państwa polskiego. Wyd. 2. Kraków: Universitas, 2006.

Biogram: prof. dr hab. Tomasz Jurek - Instytut Historii PAN, Poznań, historia średniowieczna, tnjurek@wp.pl. 